\title{
Calculation and Verification of the Behaviour of Vertical Fluid Flow Using the Multifunctional Fluid Filters
}

\author{
Kuniyo Fujiwara Non-member (Laboraotry of Advanced Science \& Technology for Industry Univ. of Hyogo) \\ Yoshiaki Ukita Student Member (Laboratory of Advanced Science \& Technology for Industry Univ. of Hyogo) \\ Toshifumi Asano Non-member (Laboratory of Advanced Science \& Technology for Industry Univ. of Hyogo) \\ Katsuhiro Matsui Non-member (Graduete. School of Engineering, Univ. of Hyogo) \\ Masahiro Takeo Non-member (Graduete. School of Engineering, Univ. of Hyogo) \\ Seiji Negoro Non-member (Graduete. School of Engineering, Univ. of Hyogo) \\ Yuuichi Utsumi Member (Laboratory of Advanced Science \& Technology for Industry Univ. of Hyogo)
}

Keywords : Microfluidics, Computational Fluid Dynamics, Deep X-ray lithography, Fluid Filter, Micro Reactor, Vertical Fluid Flow Operation

It is necessary for the biochemical and the environment analysis to be high throughput and integrated system. The vertical fluid flow operation and multifunctional fluid filter were proposed. We guessed the vertical fluid flow opration enable those system. The vertical fluid flow operation is performed using reservoirs, placed vertically, with a fluid filter separating them. To enable liquid transportation from the upper to the lower reservoirs, the fluid filter has through-capillary arrays in its body and liquid is able to

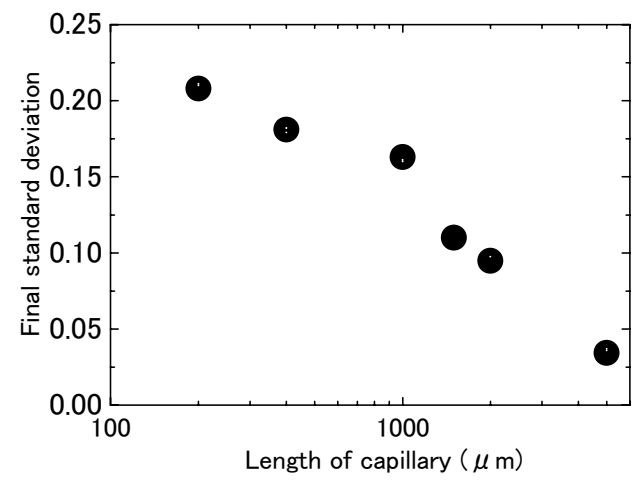

Fig. 1. The calculation result of mixing by using high aspect ratio capillary bore filter

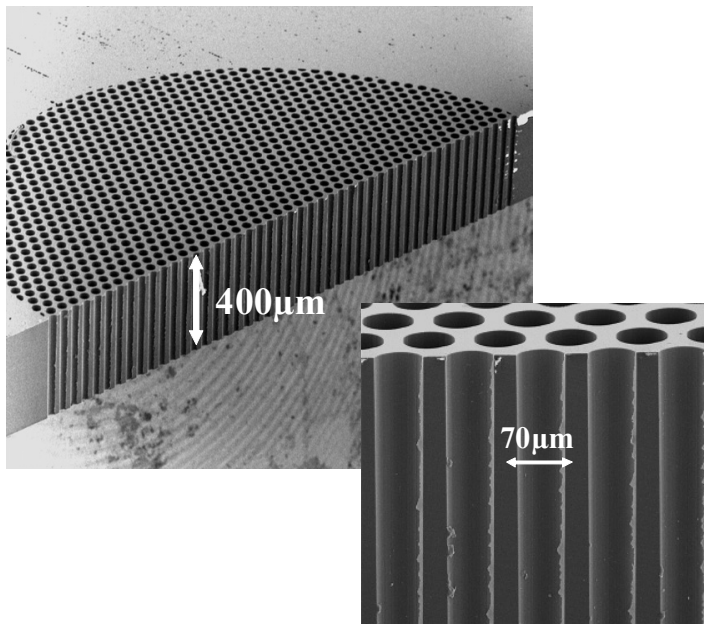

Fig. 2. SEM images of micro filter pass through the capillaries. To examine the feasibility and fluid flow properties of the vertical fluid flow operation we proposed, we calculated the flow behaviour by a computational fluid dynamics (CFD) software: FLUENT. The CFD analysis estimated the pressure threshold of fluid transportation driven by pneumatic pressure and efficiency of mixing. The results indicated useful characteristics of the vertical fluid flow operation and the good multi function of the fluid filter as channel, valve , mixer and micro reactor of the filter we proposed. Moreover, We calculated two methods for effecticve mixing using the filter. One mixing method is by iteration fluid operation and another is by high aspest ratio capillary. The fluid enough mixed at five times iteration transported through the filter. And also Fig.1 shows the relation of capillary length and standard deviation of chemical species in the mixed fluid and the low standard deviation means uniformly mixed fluid. The mixing efficiency increased with the capillary aspect ratio. So based on the results of the CFD analysis results, we fabricated the filter by Synchrotron radiate (SR) lithography. By the SR lithography the high aspect ratio sturacture can be fabricated. Figure 2 shows the SEM images of the the multifunctional fluid filters we fabricated. And we performed the flow transportation experiment using the fluid filter. As the result, the measured pressure agree the calculated threshold pressure. We demonstrated the ring-opening reaction of the Catechol by Catechol 2,3-dioxygenase as the catalyst to evaluate the performance of mixing. Figure 3 shows that the filter mixes the fluid efficiently and is enough to mix at five times transportation.

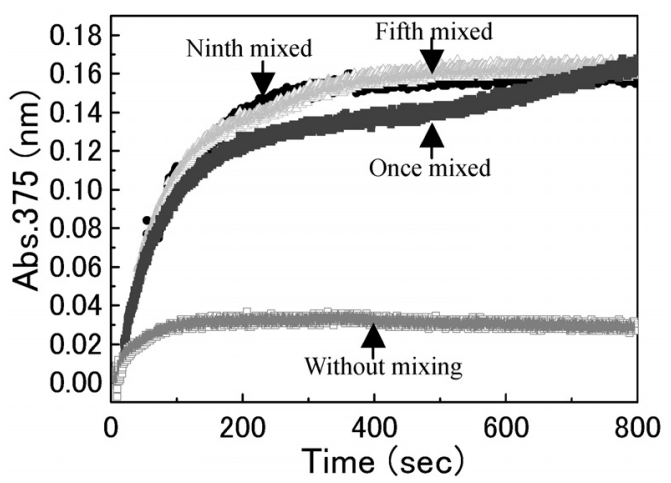

Fig. 3. mixing result by the ring-opening reaction of Catechol 


\title{
多機能フィルターを用いた垂直流体操作の挙動予測と検証
}

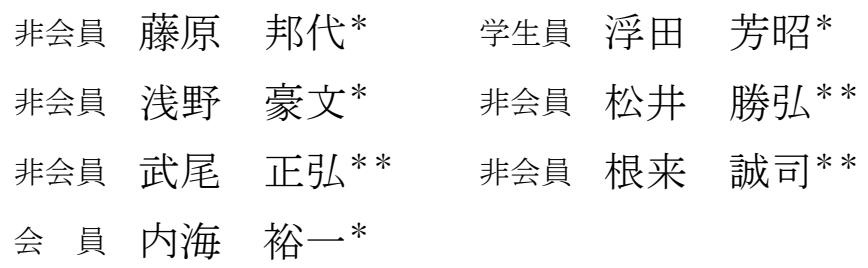

\section{Calculation and Verification of the Behaviour of Vertical Fluid Flow Using the Multifunctional Fluid Filter}

\author{
Kuniyo Fujiwara*, Non-member, Yoshiaki Ukita*, Student Member, Toshifumi Asano*, Non-member, \\ Katsuhiro Matsui**, Non-member, Masahiro Takeo**, Non-member, Seiji Negoro**, Non-member, \\ Yuuichi Utsumi *, Member
}

The vertical fluid flow operation and multifunctional fluid filter for the operation were proposed. We calculated the flow behaviour by FLUENT of the CFD software. The CFD analysis estimated the threshold pressure of flow transmission and efficiency of mixing and the results indicated that the vertical liquid transportation is useful and the good multi function as channel, valve , mixer and micro reactor of the filter we proposed. So we fabricated the filter by SR lithography and performed the flow transmission experiment. As the result, the calculated threshold pressure configurate the measured pressure. We demonstrated ring-opening reaction of the Catechol by Catechol 2,3-dioxygenase as the catalyst to evaluate the performance of mixing. It shows that the filter mixes the fluid efficiently and is enough to mix at five times transportation.

キーワード : マイクロフルイディクス, CFD, ディープX 線リソグラフィー, 流体フィルター, マイクロリアクター, 垂直流体操作

Keywords : Microfluidics, Computational Fluid Dynamics, Deep X-ray lithography, Fluid Filter, Micro Reactor, Vertical Fluid Flow Operation

\section{1. はじめに}

近年，環境問題など複雑で困難な問題を抱える社会情勢 の中で，省資源・省エネルギー化といったエネルギーや空 間を高い効率で利用することが次世代の科学技術, 産業, 社会に求められている。また，人々の健康への関心が高ま る中, オーダーメイド医療, ゲノム創薬, 遺伝子治療, な どといった各個人の遺伝的情報に基づいた臨床医療が求め られる時代となった。このような流れの中で, Lab-on-a-chip や $\mu$-TAS といった数センチ角程度の基板上に流路や反応容 器, ポンプなどの流体制御素子を集約化し，物質の合成や 検出, 分析などの化学操作をワンチップで行なうシステム が注目されている。これらは，ポータブルな実験室を実現

* 兵庫県立大学 高度産業科学技術研究所

干 678-1205 兵庫県赤穂郡上郡町光都 3-1-2

Laboratory of Advanced Science \& Technology for Industry University of Hyogo.,

3-1-2 Kouto, Kamigori, Ako-gun, hyogo 678-1205

** 兵庫県立大学 工学部物質工学専攻

干 671-2201 兵庫県姫路市書写 2167

Graduete. School of Engineering, Univ. of Hyogo,

2167 Shosya, Himiji, Hyogo, 671-2201
し, 化学操作を行なう場所を選ばないという,省スペースや ユビキタスの利点のみではなく, 反応場を微細化すること により, 物質の拡散長が短くなり, 化学反応が速く進み試 薬の量を少なくできることや，系の熱容量が小さくなるた め熱反応性がよくポリミラーゼ連鎖反応などの温度変化の 素早い操作が必要な場合に有利である。このように，高レ スポンスかつ高精度な反応制御が可能となるなどの微細化 に伴う有利点がある。

これらは，医療や環境分野に適用され，合成反応，電気 泳動分析, 蛋白質分析, 環境分析などの研究が盛んに行な われおり，マルチアレイ化などの試みも行なわれている。

今後, ポストゲノム解析や, 環境診断などの多検体の分 析への適用のため, ハイスループットや高集積・高機能化 された分析システムの必要性や, 低コスト, ディスポーザ ル化の要求がさらに高まってくることと考えられる。

\section{2. 垂直マイクロ流体操作と多機能フィルターの 提案}

現在，マイクロフルイディクスを集積化した事例の報告 
では，簡単な構造のマイクロチャネルアレイ電気泳動チッ プなどが報告されており, 最近ではポンプやバルブなどと いった，複数のアクティブな素子をシステム化，アレイ化 した高度な事例も報告されている(1)(2)。これらの事例のほと んどは，平面基板表面にマイクロ流路を表面マイクロマシ ニングにより作製したマイクロチャネルを張り合わせるな どの手法を用い，立体的にチャネルを交差させるか，同一 基板上で機能的にマイクロチャネルを配列することにより 集積化を行ったものであった。このような流路の断面は非 常に小さなものであるためスループットの不足や圧力損失 の増大, 集積数の制限などといった問題を引き起こし, 実 用化の妨げの一因となっている。更なる高集積化, 量産化 のためにはより単純な手法のほうが好ましいと考える。

本研究ではディープ X 線リソグラフィーを適用した, 基 板に垂直な方向へ流体操作を展開する新たなマイクロ流体 デバイスを提案する。垂直流体操作では，基板面に垂直な マイクロ流路により, 機能素子の積層構造を形成できる。

また, 流体挙動の自由度拡張や無効体積の削減により実 用的なデバイスが作製できる。さらに，このマイクロ流体 の挙動制御に必要なバルブ, 流路, ミキサーという機能を 集約化した多機能フィルターを提案する(3)

垂直送液の制御では，鉛直方向に設置したリザーバーを 多機能フィルターで上槽と下槽とに仕切るこの積層構造に より, 流体挙動の自由度拡張に伴う新たな挙動の発現, 無 効体積の削減による高集積化, 流路断面形状の設計性向上 が可能になる。垂直送液の一連の過程において, 多機能フ イルターの果たす役割は液体を保持するバルブの機能, 液 体を透過させるマイクロ流路の機能，液体を攪拌するミキ サーの機能であり，液体の表面張力を利用する。マイクロ 流体制御機能を一つのパッシブな素子に集約し, リソグラ フィー加工技術を用いることで容易な高集積化が期待でき る。また, この LIGA プロセスの適用により, デバイスの低 コスト化, プラスチック化, ディスポーサル化が実現可能 となり，さらに実用的なデバイスが作製可能となる。垂直 送液の概念図を示す (図 1 参照)。

\section{CFDによる解析}

〈3.1〉 閾値予測 以上に提案した概念を用いたマイ クロ流体垂直操作の可能性及び，流体挙動の特性を予測す

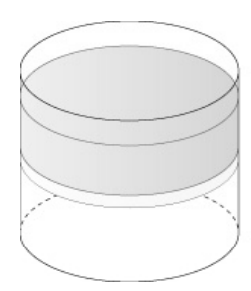

fluid holding,

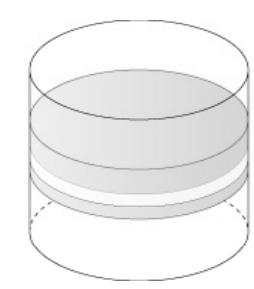

mixing,

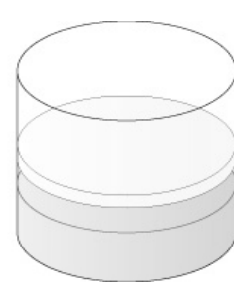

transport
図 1 垂直流体操作の概念図

Fig. 1. Schematic diagram of the vertical liquid transportation.
るため, CFD による解析を行った。本研究では, 気液, 液 液などの混相流, 壁面付着性や表面張力といった物性を取 り扱うため, 汎用性の高い熱流体解析ソフトFLUENT を用 いた。

解析は，微細な貫通孔が開いたフィルターの断面形状を モデル化して行った。フィルターの構造が流体の挙動特性 に影響することが予想されるために, さまざまな直径の微 細貫通孔による液体透過の圧力の閾值を解析した。厚さが $200 \mu \mathrm{m}$ のフィルターをモデルとして, その流路直径が $10 \mu \mathrm{m}$ から $60 \mu \mathrm{m}$ まで $10 \mu \mathrm{m}$ づつ変化させて解析した。2 次元のモ デルを使用したため, 定性的な結果を示していると考えら れる。解析の結果, フィルターと液体の親和力, フィルタ 一に開いた流路の直径が充分に小さいとき, 液体はフィル ター上に滴下しても下槽に流出せず，保持されることが分 かった。濡れ性の異なる材料をフィルターの材料に選択す ると, 疎水性の場合に比べ, 親水性の場合の閾值が数 $\mathrm{k} \mathrm{Pa}$

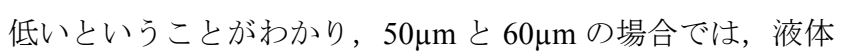
は保持されないという結果が出た。この閾值の分布は双曲 線状の分布となり, 操作圧力のオーダーは数 $\mathrm{kPa}$ から 10 数 $\mathrm{kPa}$ 程度と小さな圧力で斉むことがわかった。従来のマイク ロ流体デバイスでは流路内での圧力損失が大きいために送 液時に大きな吐出圧を必要とし, 接合部からの漏れなどの 原因となるほどだった。この解析結果が示すような, 送液 圧力に小ささは, 提案する垂直流体操作が従来のデバイス に代わるより実用的なデバイスである可能性を示す。

また, この保持状態は, 接触角の違いによりフィルター 上面での保持と下面での保持に別れることが予測された.下 面保持では, 流体はフィルターの流路内に入り込む。この ときフィルターに触媒などを付けることで透過する流体に 反応を起こさせるリアクターとしての機能が期待できる。 さらに, 保持状態から上槽に圧力を印加すると, 液体の表 面張力を圧力が打ち破り, 液体は下層一流出する。この結 果から, フィルター上に滴下した流体に圧力を加え, 印加 する圧力を変化させることで流体挙動を制御ができ, 多機 能フィルターによる垂直流体操作が可能であることを予測 している。

液体がフィルターを透過する際の挙動は複雑なものとな り，液体はフィルターを透過することにより攪挥されるこ とが予想される。

\section{〈3·2〉繰り返し送液によるミキシング効果の予測}

フィルターを透過する流体は, 微小な流路を通り流路の 外一出ることで効率のよいミキシングがなされていると予 測される。このミキシングでの流体の挙動を予測し, 効率 よくミキシングができる形状と手法の検討のためにいくつ かのミキシングパターンについて解析を行った。

初期条件で, 溶媒とする水の中に水と同じ物性を持つ化学 種が高濃度に存在する領域を作成する (図 2 参照)。これを フィルターに透過させ, 化学種の濃度の変化によりミキシ ングの効果を可視化することができる。また, 化学種濃度 の標準偏差を求めることにより, ミキシングの効果を数值 
で表した。液体がフィルターを透過する際にミキシングの 効果が発現し，パッシブで単純な構造であるが，大きなミ キシング効果があるという解析結果が得られている。液体 の送液は上層から下層への一方向のみではなく, 圧力を上 槽と下槽に交互に印加することにより，可逆的かつ，反復 的な操作が可能である。この手法により送液を 5 回繰り返 してミキシング行った際の解析結果を示す (図 3 参照)。

図 3 は, このミキシングによる, 化学種濃度の標準偏差 の時間変化を示したものである。初期状態では，化学種濃 度の標準偏差は 0.5 であり, 矢印で示すのは 1 回ごとの送液 が終了した点である。送液を繰り返すごとに標準偏差の值 が下がり, 5 回目にはほぼ流体が均一に擋拌されていること が予測された。この間の所要時間は，0.0020 秒であり，印 加圧力を上げることでさらに高速化でき, プロセス処理速 度の増大につながる。しかし, 送液用のポンプなどの高速 制御が難しいため, ポンプの切り替え制御などを必要とし ないミキシングパターンとしてフィルターの厚みを変え, アスペクト比の高い流路を 1 度だけ透過させることでミキ シングを行うことを考える。

〈3·3〉高アスペクト比ボア形状フィルターでのミキシ ング＼cjkstart流体デバイスは, 比表面積が大きくなるほど混合 の効率がよい。そこで, 高アスペクト比ボアにより比表面

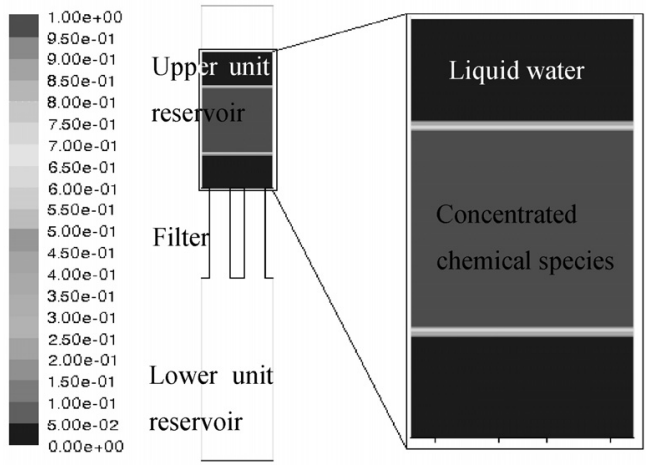

図 2 ミキシングの初期状態

Fig. 2. Initial condition of the liquid transportation.

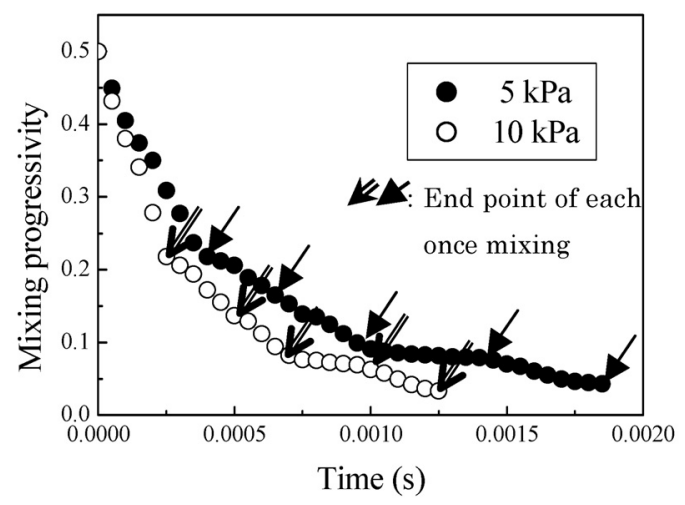

図 3 繰り返し送液によるミキシング効果の時間的推移

Fig. 3. The calculation result of mixing efficiency by iteration transport.
積を大きくしたフィルターでのミキシングの効果を解析し た。フィルター流路の直径を $40 \mu \mathrm{m}$ と一定にして, 流路の長 さを $200 \cdot 400 \cdot 800 \cdot 1000 \cdot 1500 \cdot 2000 \mu \mathrm{m}$ と変える。フィ ルターを透過し, 下層へ流れ出てミキシングが終了したと きの標準偏差の值とフィルター流路の長さの関係を表す

(図 4 参照)。

解析の結果, フィルターを透過したときの流路出口での 標準偏差の值は, 流路が長くなるに連れて小さくなる。流 路が長いほどミキシングの効果が高く, 2000 $\mu \mathrm{m}$ の流路を透 過した流体はほぼ均一に混合され, その值は繰り返し送液 を 5 回行ったときの值より小さいことが予測された。流路 を流れる流体の挙動を可視化し, 化学種の存在を示す赤色 の流体の動きを追うと, 流体は有限長さの塊の中で, 循環 しながら攪挥されていることがわかる（図 5 参照）。このよ うな流体の挙動は, 従来の平面基板を用いた流体デバイス では見られない動きであり，この垂直流体操作デバイスの 特徵的な挙動といえる。また, $2000 \mu \mathrm{m}$ の流路を透過する場 合でもかかる時間は数 $10^{-3}$ 秒程度で非常に高速なミキシン グが可能であり，このような高アスペクト比ボア形状のフ イルターを用いても $10 \mathrm{kPa}$ の圧力で送液できることが予測 された。

高アスペクト比ボアフィルターでのミキシングは入力圧 力の切り替えを必要としないため, 繰り返し送液より効率 的で実用的なミキシング手法であると考えられる。これを 用いることで, システム全体を小さくでき, ポータブルな 装置を可能にする。高効率ミキシングを可能にする, アス ペクト比の高い微細構造を持つフィルターの作成は, 放射 光によるディープX線リソグラフィーにより実現できる。

\section{4. 多機能フィルターの作製}

多機能フィルターは, 解析結果を元にX線マスクを作成 し，これを用いて放射光ディープX X 線リソグラフィーによ り作製した。光源には兵庫県, 播磨科学公園都市の SPring-8 サイト内に建設されたニュースバル放射光施設の LIGA ビ

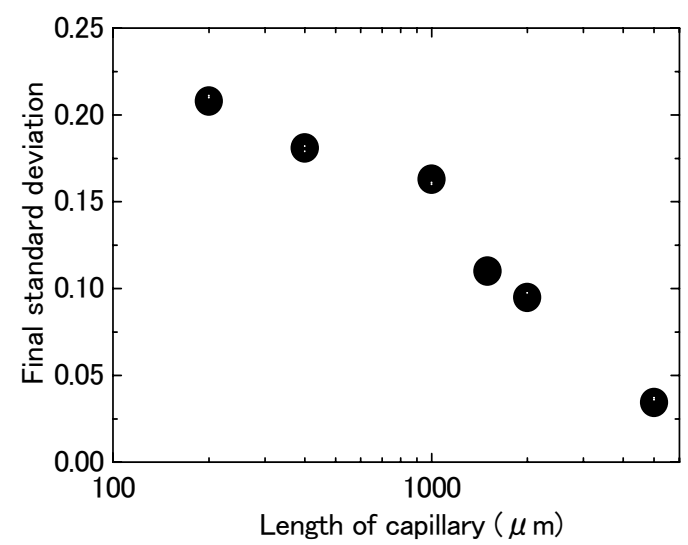

図 4 高アスペクト比ボア形状フィルターの ミキシング効果予測

Fig. 4. The calculation result of mixing by using high aspect ratio capillary bore filter. 


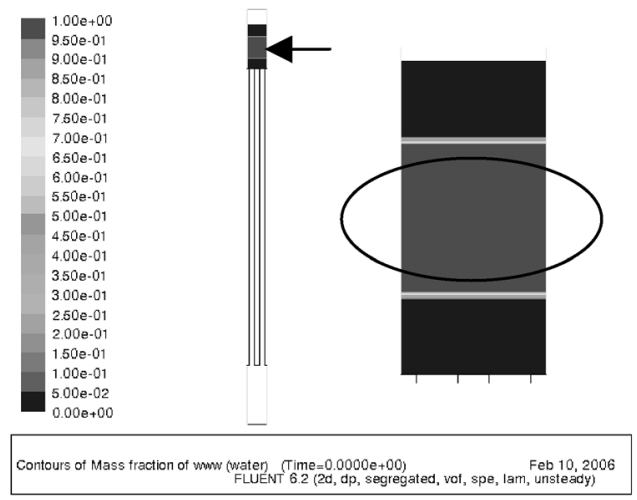

(a) $\mathrm{t}=0.0000 \mathrm{sec}$.

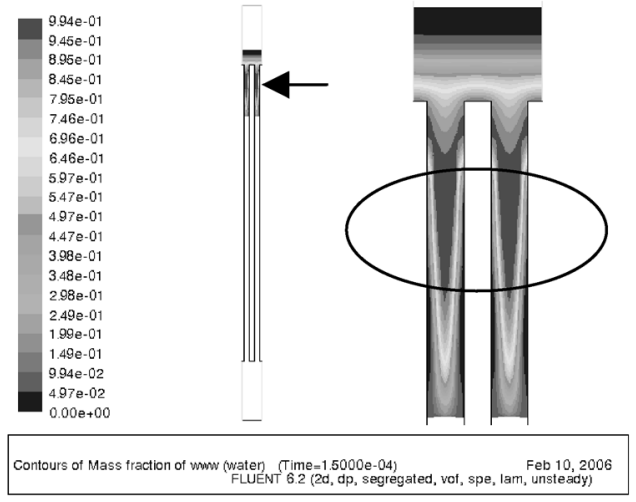

(b) $\mathrm{t}=0.00015 \mathrm{sec}$.
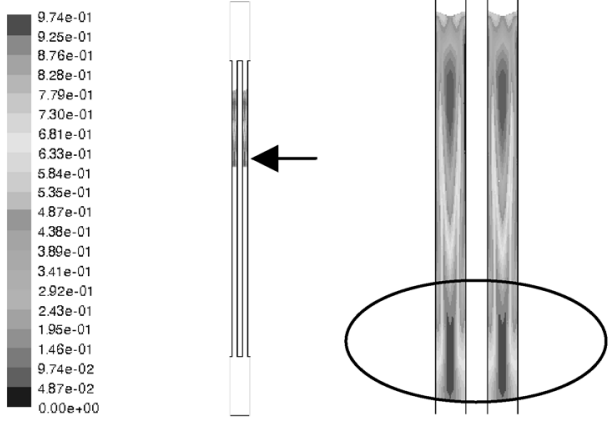

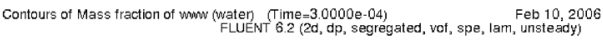

(c) $\mathrm{t}=0.00030 \mathrm{sec}$.

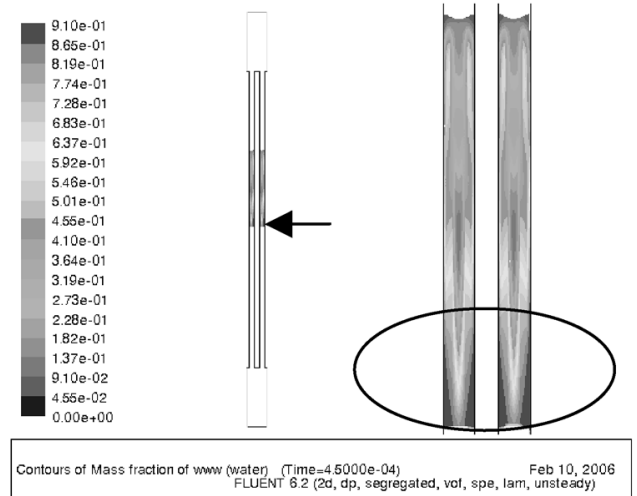

(d) $\mathrm{t}=0.00045 \mathrm{sec}$.

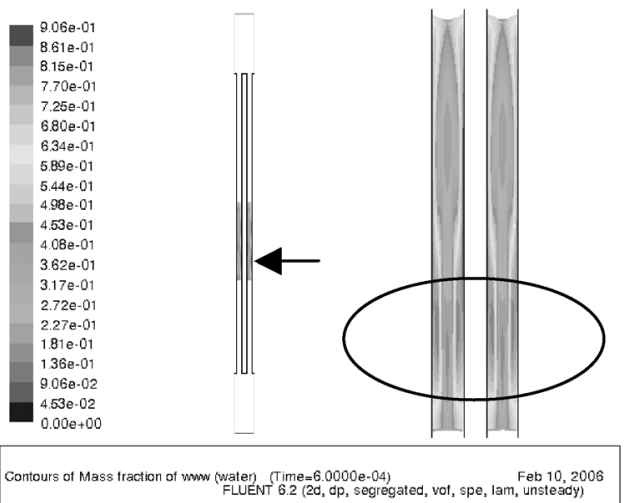

(e) $\mathrm{t}=0.00060 \mathrm{sec}$

$8.58 \mathrm{e}-01$

$7.67 \mathrm{e}-0$

$7.22 \mathrm{e}-0$.
$6.77 \mathrm{e}-0$.

$6.779-01$
$6.32 \mathrm{e}-01$
5.250 .01

$587 \mathrm{e}-0$

$5.422-0$
$4.97-0.0$

$4.51 \mathrm{e}-01$
$4.06 \mathrm{e}-01$

$4.06 \mathrm{e} \cdot 01$

$16 \mathrm{e}-0$

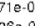

$81 \mathrm{e}-01$

$35-0$

$03 \mathrm{e}-02$

$510-02$

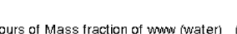

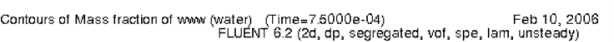

(f) $\mathrm{t}=0.00075 \mathrm{sec}$
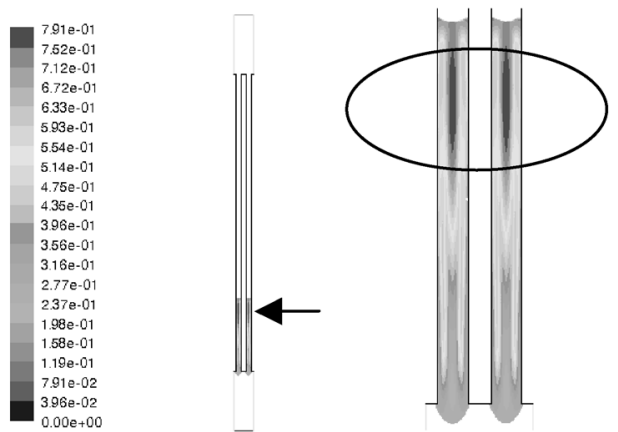

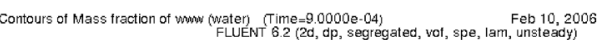

(g) $\mathrm{t}=0.00090 \mathrm{sec}$.

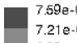

$7.59 \mathrm{e}-0$
$7.21 \mathrm{e}-0$

$6.83 \mathrm{e}-01$

$6.45 \mathrm{e}-01$
$6.07 \mathrm{e}-0$.

$6.07 \mathrm{e}-01$
$5.69-01$
53.01

$5.310-0$

$4.5 \mathrm{e}-0$.

$4.177-01$
$3792-01$
$340-01$

$3.79-011$
$3.41 \mathrm{e}-01$
$3.6-01$

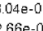

$90 \mathrm{e}-0$

$152 \mathrm{e}-0$

$14 \mathrm{e}-01$

$7.59 \mathrm{e}-02$
$3.79 \mathrm{e}-02$
$0.00 \mathrm{e}+00$

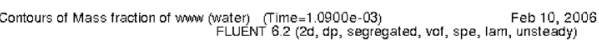

(h) $\mathrm{t}=0.00109 \mathrm{sec}$

図 5 高アスペクト比キャピラリー形状のフィルターによるミキシングでの流体挙動

Fig. 5. The fluid behaviour in the high aspect ratio capillary of the filter. 
ームライン，BL-2(4)にて行ない，レジストには PMMA のシ ートを用いた。

ディープ X 線リソグラフィーは, 他のリソグラフィーの 場合よりも高エネルギーで直進性の強い放射光を用いてい る。このため, ハイアスペクト比で高精度な加工が可能で ある。また, $\mathrm{X}$ 線マスクパターンや, 加工材料と放射光と の相対的な位置関係を変更することによって，加工形状の 選択性もある。LIGA プロセスを用いて鋳型を作れば，微細 構造を持つ多機能フィルターを大量生産でき, ディスポー ザルと低コストの要求が満たされる。

図 6 に, 設計, 製作したX 線マスク及びこの X 線マスク を用いて作製した多機能フィルターの写真を示す。フィル ターは, 厚さ $200 \sim 1500 \mu \mathrm{m}$ の PMMA シートを用いることに よりフィルター流路に長さを変化させた。直径 $12 \mathrm{~mm}$ の PMMA のプレート上で直径 $3.2 \mathrm{~mm}$ の領域にフィルター部分 があり, 微細貫通孔が約 2000 個良好な状態でアレイ化して 分布している。また, 微細貫通孔は円形形状であり, その 直径は $10 \sim 50 \mu \mathrm{m}$ の大きさである。

\section{5. 検 証}

〈5·1〉透過圧力測定 CFD 解析により多機能フィル ターの送液特性が予測され，このフィルターを用いての垂 直操作の有効性を確認した。この結果を, 実験を行い検証 する。精密機械加工により直径 $3 \mathrm{~mm}$ 長さ $12 \mathrm{~mm}$ 円筒形状の リザーバーを作製し，これにディープX線リソグラフィー により作製した多機能フィルターを組み込み，ポンプを用 い圧力空気を送り込むことでマイクロ流体垂直操作の実験 を行った。

まず, PMMA 製のフィルター上に流体を滴下したところ,

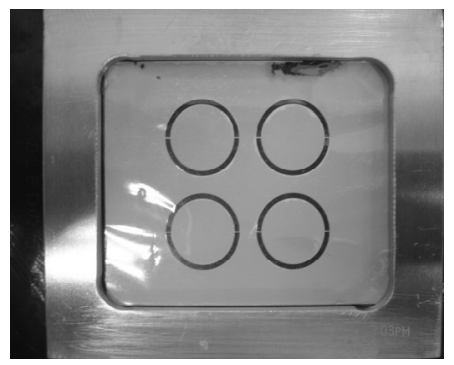

X-ray Mask
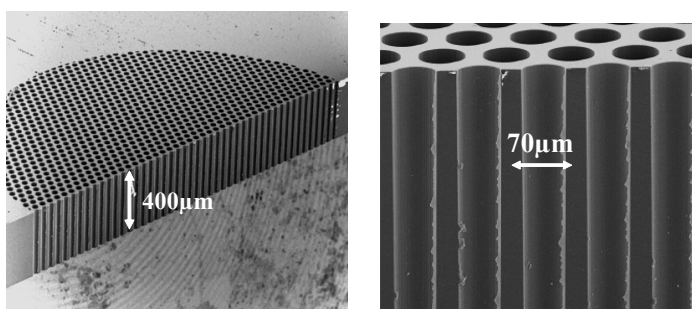

SEM images

図 6 作製したX線マスクとフィルターの写真

Fig. 6. Photos of X-ray mask and micro filter.
流体は流路内に入り込むが，フィルターから漏れ落ちるこ とはなく下面で保持された。観察のために厚さ $1000 \mu \mathrm{m}$ で直 径 $40 \mu \mathrm{m}$ のフィルターを用い着色した水を滴下したときの 写真を示す (図 7 参照)。次に, 透過圧力の閾值を測定する 手法として, フィルター上に治具で取り付けた円管に水を 流し込み, その水が流れ落ちたときの高さから透過圧力を 算出した。実験に使用したフィルターは, 流路長さ $200 \mu \mathrm{m}$ のものである。図 8 は, 解析により求めた圧力の閾值と, 実験により求めた閾值の比較である。これにより測定した 結果, 透過圧力は, 数 $\mathrm{kPa}$ という小さな值の範囲に収まっ ており, 解析結果とも良く一致している。操作圧力が小さ いことは，各素子を集積したとき，それらの接合部に過剰 な圧力がかからず, 各素子の高集積化を可能にし, 制御性 の面でも有利である。また, 流体操作の制御性を検証する ために液体流量の印加圧力依存性を測定した。印加圧力を 上げていくと液体流量もそれに比例して上昇し, 制御性が 良いことがわかった。これにより, 高分子生体化合物を扱 う場合など流体のせん断力による損傷を避ける場合は印加 圧力を下げ, 合成や分解反応などハイスループットが要求 される場合には圧力を上げることで流体操作を高速化でき る。

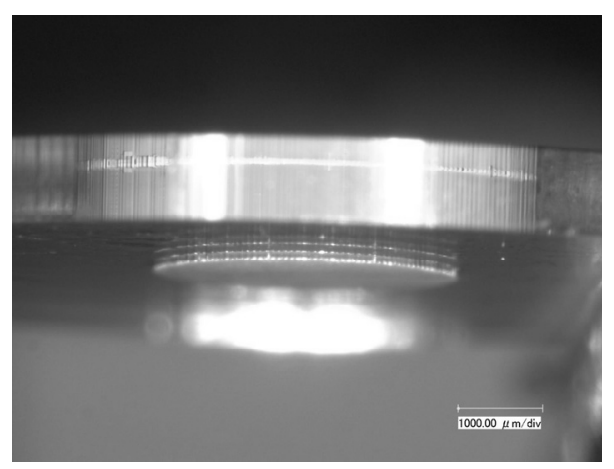

図 7 PMMA フィルターにおける流体保持の写真 Fig. 7. Photo of the PMMA filter when keep fluid.

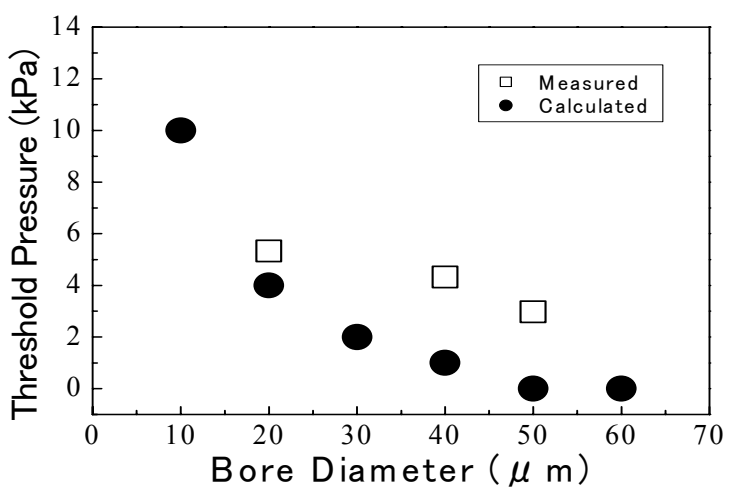

図 8 流体透過の閾值圧力の計算值と実測值

Fig. 8. Threshold Pressure of fluid transported at measured and calculated. 


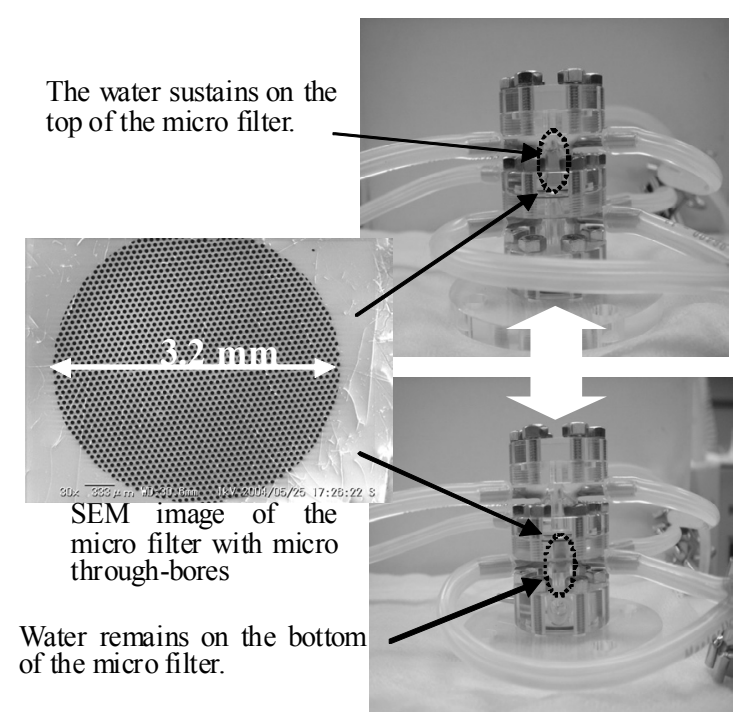

図 9 垂直流体操作の写真

Fig. 9. Photo of vertical liquid transportation.

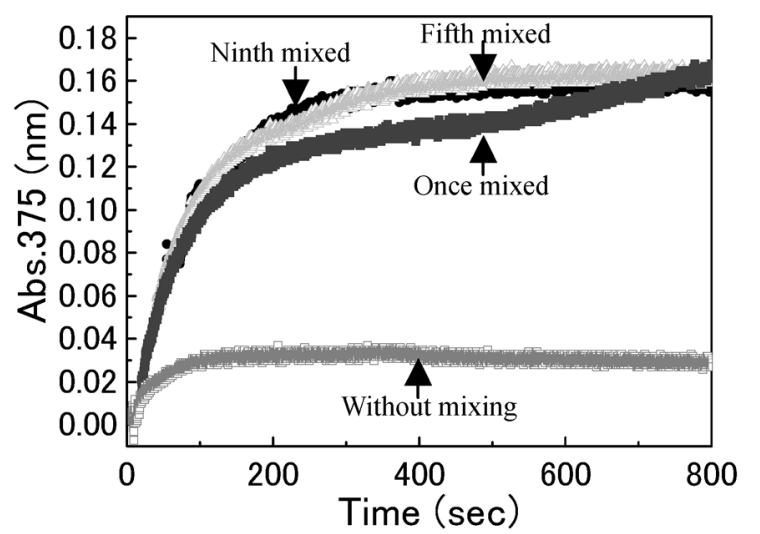

図 10 カテコールの開環反応によるミキシング効果の検証

Fig. 10. mixing result by the ring-opening reaction of

Catechol.

$\langle 5 \cdot 2\rangle$ 送液実験 前項の実験により, 多機能フィル ターの保持状態と透過圧力闇值を確認した。次に, フィル ターをリザーバーに組み込みこのリザーバー内で流体の保 持と送液を繰り返すときの送液特性について実験を行っ た。この垂直流体操作では，フィルター上に液体を滴下し た場合には解析結果と同様に液体はフィルターに保持さ れ，外圧を印加することによりフィルターを透過させるこ とができることを確認した。また，外圧の印加を上槽から 下槽に切り替えることで, 繰り返し操作も可能であること を確認した。図 9 に送液時の写真を示す。

\section{6. 混合特性}

酵素触媒反応により，フィルター透過による液体の混合 効果の評価を行った。カテコールは, 酵素（カテコール-2,3ジオキシゲナーゼ）により開環反応を触媒され，2-ヒドロキ シムコン酸セミアルデヒドを生成する。生成物は $375 \mathrm{~nm}$ に 吸収を持つため, 光ファイバー分光光度計により反応のモ
ニタリングを行った。カテコールは触媒されるとすぐ開環 反応を起こすため, 生成にかかる時間はほぼカテコールと 酵素が接触するまでにかかる時間であると考えられる。こ のため, フィルターを透過することにより溶液の混合が進 めば，カテコールと酵素が接触するまでの移動距離が短く なり反応時間を短縮できる。

測定サンプルとなるカテコール溶液, 酵素 $(\mathrm{C} 23 \mathrm{O})$ 溶液 を順に $50 \mu 1$ ずつ二通りの方法で槽内に注入した。空気によ る加圧により上下送液及び検出層へと反応液を送液し, 生 成物の $375 \mathrm{~nm}$ の吸光度を経時的に測定を行った。図 10 に測 定結果を示す。この結果より液体を流体フィルターに通過 させることで反応の立ち上がりが向上し, 反応時間の短縮 及び反応速度の向上が見られることが確認できた。また， フィルターを透過した溶液では, フィルターを透過しない 場合に比べて吸光度が高く, フィルターでのミキシングの 効率がよいことを示している。さらに, 上下送液を行い流 体が流体フィルターへの流入, 流出を繰り返すことで十分 な流体の混合効果を生み出すことが出来た。

\section{7. まとめ}

本研究は, 従来の平面的な構造をもったマイクロ流体デ バイスを立体的な構造に拡張し, 高機能・高集積・低コス 卜化を目的とした新しい流体の操作法である, マイクロ流 体垂直操作及びそれを実現しうるキャピラリー集合型多機 能フィルターを提案した。CFD 解析の結果, 本研究で提案 した手法はマイクロ流体垂直操作を可能にする見通しを得 た。

ディープ X 線リソグラフィーを用いて実際に多機能フィ ルターを作製し，送液実験を行った。その結果は予測され た流体挙動にも一致し, マイクロ流体垂直操作の全ての操 作が可能であることを示した。これらは, 垂直流体操作が 高集積化やハイスループットへの要求を満たし, 制御性の よい手段としての可能性を示す。

さらに，多機能フィルターの機能の一つであるミキシン グについて新しく提案した手法, 繰り返し送液及び高アス ペクト比流路形状フィルターでのミキシングについて, CFD 解析によりその効率のよさなどの有効性を確認した。また, カテコールを用いた酵素触媒反応によりフィルターを透過 することで高いミキシングの効果が得られ, 繰り返し送液 に於いては, 5 回の透過で流体は十分に混合できることを確 認した。

(平成 18 年 5 月 29 日受付, 平成 18 年 10 月 5 日再受付)

\section{文献}

(1) C. A. Emrich et al. : "(ULTRA) ${ }^{2}$-High Throughput Genetic Analysis Using Microfabricated Capillary Array Electrophoresis Devices", Proc. $\mu$ TAS2001, p.13-15 (2001)

(2) T. Thorsen et al. : "Microfluidic Large-Scale Integration", SCIENCE Vol.298, No.5593, p.580-584 (2002) 
( 3 ) Y. Utsumi, T. Asano, Y. Ukita, K. Matsui, M. Takeo, and S. Negoro : "A New Micro-Chemical Reactor Using Fluid Filters for Vertical Fluid Flow Operation”, Jpn. J. Appl. Phys., Vol.44, No.7B, pp.5507-5510 (2005)

(4) Y. Utsumi, T. Kishimoto, T. Hattori, and H. Hara : "Large-Area X-ray Lithography System for LIGA Process Operating in Wide Energy Range of Synchrotron Radiation", Jpn. J. Appl. Phys., Vol.44, No.7B, pp.5500-5504 (2005)
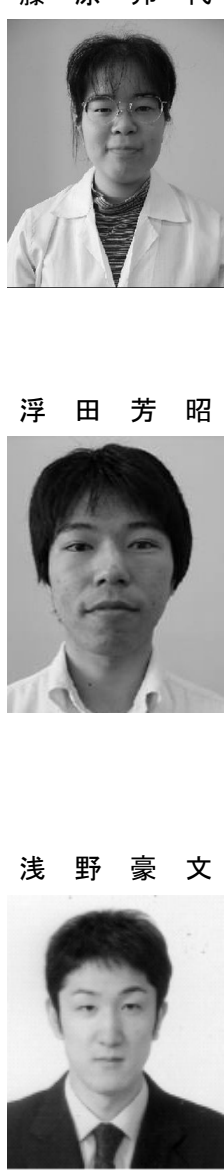

松 井 勝 弘

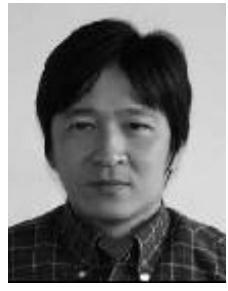

(非会員) 1970 年生。1996 年 3 月神戸大学大 学院自然科学研究科博士前期課程生物学専攻 修了。同年シスメックス（株）（旧名：東亞医 用電子 (株) 入社。現在, 社会人博士課程学生 として兵庫県立大学大学院物質系工学専攻博 士後期課程に在籍中。

武 尾 正 弘 (非会員) 1963 年生。1986 年 3 月大阪大学工

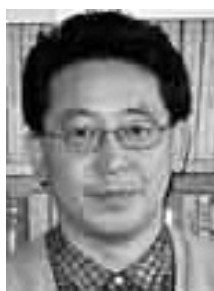
学部環境工学科卒業。1988 年 3 月大阪大学大学 院工学研究科博士前期課程環境工学専攻修了。 1988 年 4 月日清食品（株）。1991 年 7 月姫路工 業大学工学部助手, 2000 年 10 月同講師を経て, 2004 年 4 月兵庫県立大学大学院工学研究科物 質系工学専攻助教授。2000 年 9 月～2001 年 8 月ドイツ・シュツッツガルト大学客員研究員。

環境污染物質の微生物分解機構の解明と環境浄化及び分析技術の 開発を研究テーマに研究・教育に従事。

根 来 誠 司 (非会員) 1953 年生。1982 年 3 月大阪大学大

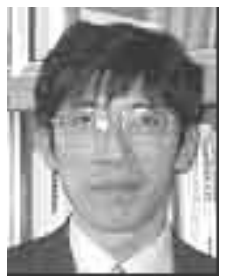
学院工学研究科酵素工学専攻博士課程修了。大 阪大学工学部助手, 助教授, 大阪大学先導的研 究オープンセンター助教授を経て 1998 年 10 月 姫路工業大学工学部教授, 2004 年 4 月兵庫県立 大学院工学研究科教授。工学博士 (大阪大学)。 非天然アミド化合物の微生物分解, 酵素の構 造・機能相関に関する研究に従事。1991 年 11 月, 題目「ナイロンオリゴマー分解系酵素とその遺伝子に関する研 究」で, 日本生物工学会斉藤賞受賞。

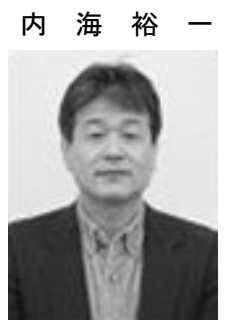

（正員） 1984 年名古屋大学大学院工学研究科 修士課程修了。同年, 日本電信電話公社入社。 物性科学基礎研究所主任研究員を経て, 2000 年 3 月より兵庫県立大学・高度産業科学技術研 究所 助教授。現在は流体デバイスを主とするナ ノ・マイクロシステム研究に従事。博士 (工学)。 日米機械学会共催・材料プロセス国際会議 2002 (M\&P2002) ベストポスター賞, 2003 年精密工 学会ベストオーガナイザー賞等を受賞。 